\title{
Toxification and detoxification of plant com- pounds by ruminants: an overview
}

\author{
G. STANLEY SMITH
}

\author{
Author is professor of animal science (metabolism and toxicology), Dep. Animal and Range Sciences, New Mexico \\ State University, Las Cruces 88003.
}

\begin{abstract}
Improved usage of rangelands for livestock production requires better ways to reduce losses caused by poisonous plants, such as management practices to minimize ingestion and treatments to improve animal tolerance of ingested poisonous plants. In ruminants, gastrointestinal microbes can detoxify plant compounds, and this capacity has been enhanced in a few cases by deliberate modification of rumen microbial populations. Some plants are poisonous because ingested plant material is made toxic by microbial fermentation in the rumen, and better understanding of such toxifications will provide opportunities to diminish poisonings of that type. Absorption of toxic substances from the gastrointestinal tract into blood and lymph may be modified by feeding binding agents such as clay, resins, and indigestible fibers, or by pharmaceuticals that interfere with absorption of toxicants. Agents that induce or inhibit biotransformational enzymes in tissues of the host animal might modify animal tolerance of some plant toxicants. Provision of substances that serve as co-substrates of detoxification can enhance animal tolerance of other types of plant toxicants. Some reports that illustrate these approaches have been reviewed, and questions have been raised to stimulate further research.
\end{abstract}

Key Words: poisonous plants, detoxification, biotransformations, ruminants

Plants that are poisonous to some animals can be harmless to others. In general, ruminants are more tolerant of poisons in plants than are nonruminants; but some plants are more toxic to ruminants. Even among ruminants, there are striking differences in tolerance of plant toxicants. For example, blossoms and seedpods of beargrass ("Sacahuista"; Nolina microcarpa Wats) cause occasionally disastrous poisoning of sheep in New Mexico, but ranchers have deliberately used cattle to graze beargrass blossoms as a way to minimize poisoning of sheep. Similarly, certain subterranean clovers impair fertility of ewes but have far lesser effects on cows. And Senecio species that are highly toxic to cattle, horses, swine, rats, and chickens seem less toxic to sheep, goats, rabbits, guinea pigs, and Japanese quail. Such differences in tolerance of toxicants that are unrelated to phylogenetic classifications are now explainable, at least in part, by toxicological principles that have been learned; and these may provide opportunity to modify toxification processes and to enhance detoxification processes.

The body of generalized knowledge about poisonous plants that affect livestock has been summarized by Kingsbury (1964), National Research Council (1973), Cheeke and Shull (1985), Seawright et al. (1988), James et al. (1988), and a series edited by Cheeke (1989). \footnotetext{
Special publication 364 of the New Mexico Agr. Exp. Sta., presented as an invited
paper at a Symposium of "Ingestion of Poisonous Plants by Livestock" at the 1990 Annual Meeting of the Society for Range Management (February 15, 1990; Reno, Nev).

Manuscript accepted 28 May 1991.
}

For textual summaries of toxicological principles see Casarett and Doull's Toxicology: The Science of Poisons (Klaassen et al. 1986), Nutritional Toxicology, Vol I and II (Hathcock 1982, 1986) and Gastrointestinal Toxicology (Rozman and Hanninen 1986).

In ruminants, tolerance of poisonous plants may be modified by microbial fermentation of ingesta in the reticulorumen (which can diminish toxicity of some plant compounds and increase toxicity of others). Some plant compounds may be sequestered in the gut by adsorbents or binding agents administered through feed or water, thereby affording greater tolerance. And some plant compounds may be biotransformed within tissues of the host ruminant yielding products that are more toxic or less toxic than the plant compound ingested. These biotransformations might be induced to favor detoxifications or inhibited to suppress toxications, when animal metabolism of plant toxicants has been characterized.

This report is not intended to review the extensive literature that deals with metabolism of plant toxicants by ruminants. Rather, it provides an overview of toxifications and detoxifications by ruminants and should introduce the uninitiated readers to some principles that could guide researchers in development of protocols for increasing the tolerance of poisonous plants by ruminants.

\section{Rumen Microbial Toxifications and Detoxifications}

Ruminants tolerate many poisonous plants far better than nonruminants. It has been suggested that rumen microbial detoxification of poisonous plants might have been as important as rumen microbial degradation of cellulose for the evolutionary development and ecological expansion of ruminants as herbivores (Freeland and Janzen 1974, Van Soest 1982). James and associates (1975) reviewed earlier literature on rumen detoxifications and called attention to known or suspected toxifications by microbial activities in the reticulorumen. Consideration of rumen toxifications and detoxifications was expanded by Smith (1986) in relation to prospective recycling municipal sewage, animal wastes, and other exotic feedstuffs.

Microbial populations change gradually with prolonged, increasing exposure to toxic substances, and such gradual adaptations allow ruminants to increase their tolerance of some poisonous plants. It has been established that microbial adaptations provide detoxification of plant toxicants such as nitrate, nitrite, nitropropanoic acid, oxalate, prussic acid (and cyanogenic glycosides), sulfate and sulfide, some alkaloids (e.g., mimosine) and, perhaps, even some mycotoxins (James et al. 1975, 1988; Smith 1986; Seawright et al. 1988; Daniel et al. 1989; Allison et al. 1989; see also other reports from this Symposium). It is widely appreciated that microbial adaptations allowing detoxifications such as these require initial exposure at low dosage and gradual increase in dosage. The development of special microbial cultures that can detoxify specific plant toxicants seems highly promising as a means to manage animal exposure to some poisonous plants.

What seems less generally understood is the fact that gradual 
ruminal changes, which could increase ruminant tolerances of poisonous plants, might be lost suddenly. This was illustrated almost 30 years ago in an experiment at the Unversity of Illinois (Hatfield and Smith 1963). Although it dealt with nitrate added to the diet as a pure chemical rather than nitrate in a poisonous plant, the principle is the same. Lambs were fed a diet with $69 \%$ ground corn in which either soybean meal or urea provided most of the supplemental nitrogen. Potassium nitrate was included in diets of some lambs as $1.5 \%$ of ration for 55 days, as $4.0 \%$ of ration for the next 25 days and as $5.0 \%$ of ration for another 23 days. Lambs fed soybean meal gained more weight than those fed urea, and nitrate reduced gains by lambs fed soybean meal, as was expected. Unexpectedly, dietary nitrate increased gains of lambs fed diets with urea as main nitrogen source. Also unexpectedly, some lambs that had adapted to the diet with added nitrate were acutely poisoned when their nitrate-containing diet was replaced after a similar, but nitrate-free, diet had been substituted for only one day (G.S. Smith and E.E. Hatfield, unpublished data).

Animal tolerance of poisonous plants that might require microbial adaptation over many days of gradually increasing ingestion of toxicant could similarly be lost through changes of diet lasting only a few hours. For cattle and sheep on rangelands the management of supplements, water, or movement among grazing areas could contribute to, or detract from, the adaptations that allow detoxification of ingested poisonous plants.

\section{Sequestration and Binding of Toxicants}

Some kinds of plant toxicants can be sequestered in the ingesta, thereby preventing their absorption from the gastrointestinal tract and, in essence, providing detoxification. Activated charcoal has been used effectively to adsorb some kinds of poisons and prevent their absorption (Buck et al. 1982, Klaassen et al. 1986). Specialized resins, such as cholestryramine (which adsorbs compounds like cholesterol and lipophilic pesticide residues like DDT and heptachlor), can be selected or developed specifically to sequester restricted types of compounds and thereby diminish absorption or toxic substances. Some clays in their natural form have capacities to bind certain types of toxicants, and others can be modified in ways that enhance the binding of specific types of chemicals. The inclusion of a specific type of clay (HSCAS; hydrated sodium calcium aluminosilicate; "Novasil"TM) into diets for animals fed moldy grain has effectively diminished absorption of mycotoxins such as aflatoxin (USDA-ARS 1990). This approach has wide possibilities in regard to livestock managed under circumstances that afford administration of treatments in feed supplements consumed daily. Livestock grazing rangelands, where daily monitoring or daily provision of supplemental feeds is unfeasible, would benefit more consistently from binding agents such as colloidal clays that could be suspended in the drinking water.

\section{Biotransformation of Absorbed Compounds}

When plants are ingested by animals, numerous substances other than nutrients generally are absorbed from the gut, transported through the circulatory system (lymph as well as blood) to various organs and tissues, metabolized from "parent compounds" (i.e., whatever forms that were absorbed) to various metabolites (altered forms), and then excreted in some form. Many examples are available in the literature about poisonous plants, showing that nontoxic substances in plants can be converted in the animal tissues to metabolites that cause poisoning (see Cheeke 1989). Animals vary widely in their capacities to biotransform absorbed drugs, xenobiotics, and nonnutritive substances in plants, and differences among species have been emphasized (Oser 1981, Caldwell 1989). Toxicological studies often require usage of some species as models or surrogates of other species, but proper usage requires careful interpretations and cautious extrapolations.

Substances absorbed from the gut into blood usually pass to the liver which, therefore, has "first pass" in metabolism of nutrients and biotransformations of nonnutrient substances. Using 8 species of laboratory animals commonly used in toxicity testing, Gregus et al. (1983) compared activities of biotransformational enzymes in their livers. Trout, quail, mice, rats, guinea pigs, rabbits, cats, and dogs were similar in respect to some biotransformational enzymes and very dissimilar in others. In some cases, livers of trout or quail resembled livers of rats more than livers of mice did. Biotransformational enzyme activities in these species varied widely and in ways not explained by phylogenetic relationships. Smith and associates (1984) similarly studied biotransformational enzymes in livers of rats, swine, sheep, and cattle, under circumstances allowing comparisons of results with those reported by Gregus et al. (1983). Liver data from swine, sheep, and cattle were compared with liver data from dogs, cats, rabbits, guinea pigs, rats, mice, quail, and trout by Watkins and Klaassen (1986), who concluded (p. 933):

Several hundred- to several thousand-fold differences between species in enzymatic activities for certain substrates under well defined conditions emphasize the need for caution and the risk of error in extrapolation of xenobiotic metabolism from one species to another. In spite of these uncertainties, knowledge of the rate of biotransformation may help us predict the fate of new chemicals in various species.

Comparative hepatic data from Watkins and Klaasen (1986) are shown in Figure 1 (reprinted from J. Anim. Sci. with permission of editor).
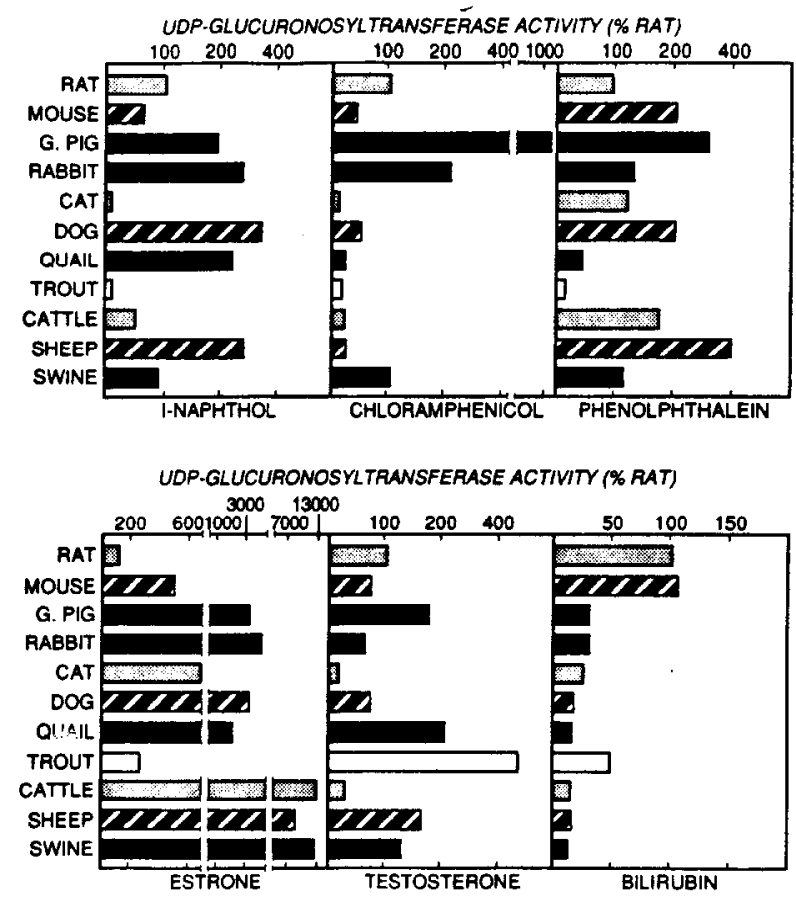

Fig. 1. Species variation in hepatic microsomal UDP-glucuronosyltransferase activity toward 1-naphthol, chloramphenicol and phenolphtaelein (top figure), and estrone, testosterone and bilirubin (bottom figure). Data are expressed as a percentage of the value obtained for rat liver.

If species " $A$ " differs from species " $B$ " by 100 -fold in regard to activities of a particular hepatic enzyme that biotransforms a particular toxicant, that should not imply that species " $A$ " is 100 -fold more tolerant of (or susceptible to) that toxicant than species "B". It does suggest that they might differ greatly, and probably would differ greatly, if the toxicant under consideration should reach the livers of these species in similar form and equal amounts. But 
Table 1. Protein concentrations in tissue preparations, microsomal cytochrome P-450 contents, and activities of biotransformational enzymes in cytosolic and microsomal fractions of hepatic, renal, and ileal tissues froms cows and ewes ${ }^{\text {abc }}$.

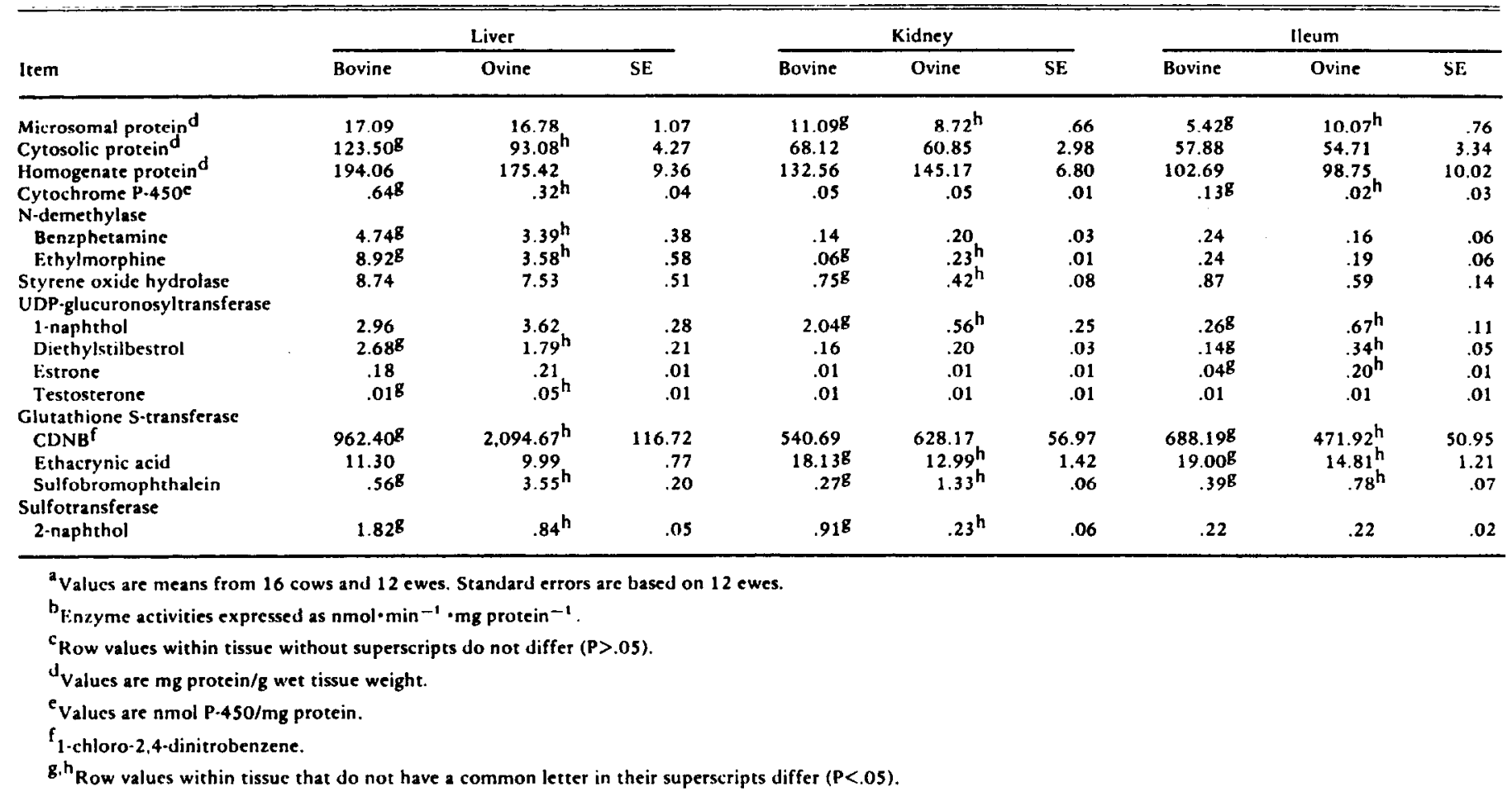

findings of Gregus et al. (1983), Smith et al. (1984), Watkins and Klaassen (1986), and Watkins et al. (1987) show only baseline ciata for hepatic activities under standardized circumstances. They do not reveal how much these enzyme activities might be increased or decreased if the animals had been exposed previously to substances that could induce or inhibit such enzymes.

\section{Enzyme Induction}

Phase I biotransformational enzyme activities (oxidative and reductive changes) can be induced several fold, especially in livers (Parke 1975, Hodgson and Levi 1987), and some phase II biotransformations (conjugative reactions) may be increased 100 -fold or 1,000 -fold by prior exposure to appropriate inducers (Thompson et al. 1982, Kato et al. 1989). These findings help to explain why a particular plant, with a constant amount of toxicant, might poison a particular animal at one time of exposure and yet prove harmless to the same animal at another time under a different circumstance of exposure.

Blood draining the gut (via mesenteric veins) passes first through the liver (via portal vein) and then to the right auricle of the heart (via hepatic vein and vena cava). From the right auricle through the right ventricle of the heart, blood then goes to the lungs (via pulmonary artery) and returns (via pulmonary vein) to the heart. Thereafter, the blood circulates to all tissues of the body, including heart tissue. Understanding this route of exposure to toxicants, via blood, is essential to understanding what may happen when animals are poisoned by ingestion of plants. The nature of poisoning (toxicosis) may vary greatly, simply because the amounts of "parent compounds" and their metabolites that reach various organs or tissues can vary widely under what would seem to be similar circumstances. Dietary factors that change patterns of blood flow (e.g., shunting of blood to or from the kidneys) can alter substantially the patterns of xenobiotic toxicities.

\section{Gut Tissue Biotransformations}

For much too long, the liver has been regarded as the organ which has "first pass" at biotransformation of drugs, xenobiotics, and dietary toxicants. Very often what reaches the liver is not what was ingested: the gut tissue really has "first pass", and biotransformational enzyme activities in gut tissue may be more important, in some cases, than the activities of enzymes in the liver (Laitenen and Wakins 1986). Watkins et al. (1987) compared biotransformational activities in hepatic, renal and ileal tissues of cattle and sheep (see Table 1, reprinted from J. Anim. Sci., with permission of editor).

In most cases, livers had higher activities of biotransformational enzymes than kidneys or ileal tissue. Also, cattle and sheep differed remarkably in activities of certain enzymes in kidneys and ileum, as they had been shown to differ in liver enzyme activities. For example, cytochrome P-450 levels (Table 1) were two-fold higher in livers of cattle than sheep and six-fold higher in ileum of sheep; but glutathione-S-transferase activity using CDNB as substrate (Table 1) was two-fold higher in livers of sheep than livers of cattle. In the same study (Watkins et al. 1987), activity of UDPglucuronosyl-transferase in rumen wall tissue of sheep (not shown in Table 1) was three-fold higher than tissues of liver or ileum (when estrone was the substrate), and sixty-fold higher than kidncy tissue.

How important are the biotransformational activities that occur in gut tissue, in comparison with hepatic or renal metabolism of plant toxicants? How quickly, and to what extend, do biotransformational enzymes respond to inducers or inhibitors that may appear in the ingesta? Dr. Phil Dziuk (professor emeritus, Dept. Animal Science, University of Illinois) has postulated that extensive and rapid changes in biotransformational enzymes of gastrointestinal mucosa are far more important to animal metabolism of drugs, xenobiotics, and alellochemicals in plants than most of the current literature suggests (personal communications with G.S. Smith 1989-90). In his student's research, some orally administered drugs and compounds with sex hormone activity were biotransformed and totally conjugated during passage into portal blood, i.e., before reaching the liver (Ruoff 1988). 


\section{Co-substrates of Detoxification}

Phase I biotransformations (oxidative-reductive, hydrolative changes) in tissues make lipophilic plant compounds more watersoluble and, generally, more reactive. Subsequently, they may undergo Phase II biotransformations by which they are conjugated with substances produced endogenously, such as glucuronic acid, glutathione, acetate, glycine, taurine, and sulfate.

These conjugative substances are sometimes called "co-substrates of detoxification" because their reaction productions are usually more rapidly excreted and often less toxic, than the unconjugated compounds. When such "co-substrates of detoxification" are abundant in animal tissues, certain kinds of toxicants can be readily detoxified and thus well tolerated in the diet; but when these co-substrates are deficient in tissues (which can occur by rapid depletion under some circumstances), tolerance of toxicants can be lost or diminished. There are numerous examples in which animals have been depleted of co-substrates of detoxification and thereby made susceptible to poisonous plants that otherwise were tolerated (Cheeke and Shull 1982, Klaassen et al. 1986, Cheeke 1989, Kato et al. 1989). Conversely, there are examples in recent literature whereby co-substrates of detoxification were supplied exogenously (through feed, water, or parenteral administration) and animal tolerances of toxicants were thereby increased remarkably (Klaassen et al. 1986, Cheeke 1989).

\section{Toxicity of Plants Depends on Tolerance by A nimals}

When an important co-substrate of detoxification is unavailable, for whatever reason, an alternate pathway of metabolism may become dominant and thereby change detoxification into a process yielding metabolites that are more toxic than either the absorbed parent compound(s) or the normally predominant metabolites. Thus, toxicity of an ingested plant may not be determined solely by the amount of toxic substance(s) contained in the plant tissues, or even by the amounts of toxic substances ingested by a particular animal. Rather, toxicity is affected by numerous factors, such as: rates of ingestion; types and rates of microbial transformations in the rumen; rates of gastrointestinal absorption; rates and pathways of biotransformations in gut tissue, liver, and kidney; availability of co-substrates for conjugative biotransformation; and effects of enzyme inducers or inhibitors. Tolerance or intolerance by animals can be subject to considerable changes, and previous management of grazing ruminants may have substantial effects on tolerance of poisonous plants.

Kochia scoparia (L.) Schrad. is a hardy, drought-resistant plant that produces high yields of forage with low requirements for water. Its development as a forage crop for irrigated arid areas has been constrained by occasional livestock poisoning (Sprowls 1981, Kiesling et al. 1984, Smith et al. 1989). To assess nutritive value and possible toxicity of Kochia scoparia cultivated with irrigation and grazed as lush forage, scientists in New Mexico allowed cattle to graze the sample plots of kochia in 3 successive years. Toxicosis was observed with each group of cattle that grazed kochia, every year of the study; but toxicosis varied from mild to severe when different groups of cattle grazed at different times, even though the plants were at similar phenological states when grazed (Thilsted et al. 1989). Measurements of presumed toxicants in the plant herbage, such as nitrate, oxalate, and alkaloids (assayed grossly), provided little, if any, index of toxicity. The authors presumed that varied severity of toxicosis (in different groups of cattle grazing the same plot of kochia at different times) was caused by varied concentration of toxicant in the forage grazed. It was a reasonable presumption, and it is typical of such presumptions in many reports about poisonous plants grazed by livestock. But there was no discussion about possible differences in the groups of cattle that grazed these plots (breed, condition, previous diet, earlier man- agement, etc.), which might have influenced animal tolerance of the toxic substance(s) in the forage grazed. More consideration should be given to factors that affect animal tolerance of toxicants.

Typically, agriculturalists have found it expedient to reduce the toxicants in plants that are agronomically important. But occasionally some agronomically important feature is related directly to plant content of substances that impact negatively on animals, so that efforts to improve animal tolerance of toxicants become more important than efforts to reduce plant content of toxicant. A classic example is tall fescue (Festuca arundinacea Schreb), which is cultivated on vast acreages of pastureland and grazed extensively by livestock, despite the fact that animals often perform poorly and sometimes experience overt "fescue toxicosis". The factor that lends agronomic benefits (endophyte infestation) is related to plant content of substances (clavine alkaloids) that impair animal performance and, in extreme cases, cause overt toxicosis. Rather than removal of endophyte from the plants being cultivated, recent effort has been directed toward improving livestock tolerance of endophyte-infested fescue forage. In research by Lipham et al. (1989), cattle grazing endophyte-infested tall fescue were managed with or without oral administration of the drug metoclopramide. Steers given metoclopramide gained favorably $(.314 \mathrm{~kg} / \mathrm{d})$ while similar, untreated steers gained poorly $(.150 \mathrm{~kg} / \mathrm{d})$ and developed signs of toxicosis.

Because kochia toxicosis had been characterized with some features that resemble fescue toxicosis (Rankins and Smith 1991; Rankins et al. 1991a,b) metoclopramide treatment was attempted as a way to improve livestock tolerance of toxicants in kochia hay (Rankins et al. 1991c). The effort was unsuccessful, but dosage of metoclopramide may have been improper because activity of metoclopramide, per unit weight, reportedly can vary among sources and suppliers of this drug (J.A. Stuedeman and R.D. Jones, USDA-ARS, Watkinsville, Ga.; personal communication to G.S. Smith, 1991). Further efforts in this direction should be dependent on proper characterization of the animal responses to the poisonous plant as ingested (and not merely to a specific toxicant studied independently of other substances in the plant), and the consequent development of specific therapies to enhance animal tolerance.

\section{What Determines Toxicity?}

The dose:response relationship is a fundamental principle of toxicology. As the dosage increases, the animal response also increases correspondingly. But the concentration of a substance in a plant may be a poor index of how animals may respond when they ingest such plants. The amount of plant material consumed is a general index of "dose", but it is not necessarily a good index of dosage. Even the total amount of toxicant consumed (if such data were available) might not be a good index of dosage. The amount absorbed is a far better index of dosage; but even that may be inadequate to provide predictability of animal response, because rate of absorption (as well as amount) can modify pathways of metabolism, routes, and extent of biotransformation and rates of excretion. All of these factors will modify the amounts of toxicant that reach a particular site of action, where tissue damage or specific toxic effect actually occurs.

In general, the concentration of toxicant that develops in blood after ingestion of a poisonous plant may be regarded as an index of dosage. But even the concentration in blood may not adequately reflect "dosage" at the site of action. In other words, individual animals may vary quite widely in their toxicological response to the same concentration of a specific toxicant in their blood stream. Such circumstances have been observed in the way cattle and sheep are affected by estrogenic substances in clovers. Sheep are more sensitive to these clovers than cattle, and fertility is impaired more severely. Explanation for the difference in species sensitivity was 
sought for several years in terms of microbial metabolism, gut transformation, hepatic biotransformation, etc. Recent studies determined that the active form of plant estrogen (equol) is produced more actively by cows and occurs at higher levels in blood of cows than in blood of sheep eating the same clovers (Lundh 1990; Lundh et al. 1990); yet sheep show greater response to any given concentration of equol in blood than cows do. Such differences in sensitivity (tolerance) of cows versus sheep seem unrelated to principles discussed above, i.e., differences in animal capacities to "toxify" or "detoxify" some particular compound that is absorbed and metabolized. Rather, there seems to be differences in tissue response at the site of action. How can such differences be explained and how could such information be useful in management of livestock exposed to these estrogenic classes?

It seems plausible that some toxicants reach their site of action the way glucose enters cells, and that levels in blood may reflect very poorly how much is being absorbed into cells. In such cases, a high level of toxicant in blood may reflect poor absorption into cells and indirectly, relative tolerance of that toxicant.

There may be some toxicants that affect tissues in ways that are analogous to how diabetes affects humans. Usually diabetes (high blood glucose levels) occurs because there is a lack of insulin to facilitate glucose transport out of blood and into cells; but in some cases of diabetes, blood levels of insulin are normal or even elevated. It is the lack of insulin receptors that cause some cases of diabetes. In a similar (analogous) way, some animals may tolerate toxicants in their blood at levels that would impair animals of another species (or even the same species) simply because they lack appropriate "channels" (or appropriately activated channels) to convey the toxicant from blood to appropriate sites of action. Such would seem to be an explanation for why cows can tolerate higher levels of equol in their blood than sheep (Lundh et al. 1990) without comparably adverse effects on fertility.

Further research is needed not only to identify the toxicants in poisonous plants that affect productivity of livestock but also to characterize the toxicoses, to identify modes of action and pathways of metabolism or biotransformations, and to test protocols of various types that may improve animal tolerances of the compounds that cause plants to be poisonous.

\section{Summary}

The compounds in poisonous plants that cause adversity in ruminants are subject to chemical transformations not only by rumen microbes but also by enzymatic changes in gut mucosa, liver, kidney, and other tissues. Some chemical changes increase toxicity of plant compounds and some cause detoxification. Animal management or treatment protocols may alter rumen microbial toxifications or detoxifications. Administration of sequestering agents via feedstuffs or drinking water could diminish gastrointestinal absorption of some toxic plant compounds. Transformations of toxicants at the host tissue level may likewise be altered by induction or inhibition of certain biotransformation enzymes, or by altered availability of co-substrates that may favor one pathway of biotransformation over another.

Although concentration of toxicant in blood is usually a reliable index of dosage in regard to dose:response relationships, some animals may lack sensitivity to toxicants because channels of passage to site of action are missing, nonfunctional or blocked. Understanding such cases might provide additional opportunities for improving animal tolerances of toxicants in poisonous plants.

\section{Literature Cited}

Allison, M.J., A.C. Hammond, and R.A. Jones. 1990. Detection of rumen bacteria that degrade toxic dihydroxypyridine compounds produced from mimosine. Appl. Environ. Microbiol. 56:590-594.
Buck, W..B., G.D. Osweiler, and G.A. Van Gelder. 1982. Clinical and diagnostic veterinary toxicology (2nd Edit). Kendall/Hunt Publ. Co., Dubuque, Ia.

Caldwell, J., A. Weil, and Y. Tanaka. 1989. Species differences in xenobiotic conjugation. p. 217-224. In: R. Kato, R.W. Estabrook and M.N. Cayen (Eds.), Xenobiotic metabolism and disposition (Proc. 2nd Int. ISSX Meeting, Kobe; 1988). Taylor and Francis, New York.

Cheeke, Peter R. (Ed.). 1989. Toxicants of plant origin. Vol. I, Alkaloids; Vol. II, Glycosides; Vol. III, Proteins and amino acids; Vol. IV, Phenolics. CRC Press, Inc., Baca Raton, Fla.

Cheeke, P.R., and L.R. Shull. 1985. Natural toxicants in feeds and poisonous plants. AVI Publ. Co., Westpoint, Conn.

Daniel, S.L., H.M. Cook, P.A. Hartman, and M.J. Allison. 1989. Enumeration of anaerobic oxalate-degrading bacteria in the ruminal contents of sheep. FEMS Microbiol. Ecol. 62:329-334.

Freeland, W.J., and D.H. Janzen. 1974. Strategies in herbivory by mammals: the role of plant secondary compounds. Amer. Natur. 108:269-289.

Gregus, Z., J.B. Watkins, T.N. Thompson, M.J. Harvey, K. Rozman, and C.D. Klaassen. 1983. Hepatic phase I and phase II biotransformations in quail and trout: comparison to other species commonly used in toxicity testing. Toxicol. Appl. Pharmacol. 67:430-441.

Hatfield, E.E., and G.S. Smith. 1963. Nitrate and urea in rations of feeder lambs. J. Anim. Sci. 22:1122 (Abstr.).

Hathcock, John N. (Ed.). 1982. Nutritional toxicology, Vol. I. Academic Press, New York.

Hathcock, John N. (Ed.). 1986. Nutritional toxicology, Vol. II. Academic Press, New York.

Hodgson, Ernest, and Patricia E. Levi. 1987. Modern toxicology. Elsevier Science Publ. Co., Inc. New York.

James, L.F., M.J. Allison, and E.T. Littledike. 1975. Production and modification of toxic substances in the rumen. p. 576-590. In: I.W McDonald and A.C.I. Warner (Eds.), Digestion and metabolism in the ruminant. Univ. New England Publ. Unit, Armidale, N.S.W., Australia.

James, L.F., Michael H. Ralphs, and D.B. Nielsen (Eds.). 1988. The ecology and economic impact of poisonous plants on livestock production. Westview Press, Boulder, Colo.

Kato, R., R.W. Estabrook, and M.N. Cayen (Eds.). 1989. Xenobiotic metabolism and disposition (Proc. 2nd. Int. ISSX Meeting, Kobe; 1988). Taylor \& Francis Ltd, London.

Kiesling, H.E., R.E. Kirksey, D.M. Hallford, M.E. Grigsby, and J.P. Thilsted. 1984. Nutritive value and toxicity problems of kochia for yearling steers. New Mexico Agr. Exp. Sta. Res. Rep. 546.

Kingsbury, J.M. 1964. Poisonous plants of the United States and Canada. Prentice-Hall, Englewood Cliffs, N.J.

Klanssen, C.D., Mary O. Amdur, and J. Doull (Eds.). 1986. Casarett and Doull's toxicology: The basic science of poisons (3rd Ed.). Macmillan Publ. Co., New York.

Laitinen, M., and J. Watkins. 1986. Mucosal biotransformations (Ch 6, p. 169-185) In: K. Rozman and O. Hanninen (Eds). Gastrointestinal toxicology. Elsevier Science Publ., Amsterdam.

Lipham, L.B., F.N. Thompson, J.A. Stuedemann, and J.L. Sartin. 1989. Effects of metoclopramide on steers grazing endophyte-infected fescue. J. Anim. Sci. 67:1090-1097.

Lundh, T.J-O. 1990. Conjugation of the plant estrogens formononetin and diadzein and their metabolite equol by gastrointestinal epithelium from cattle and sheep. J. Agr. Food Chem. 38:1013-1016.

Lundh, T.J-0., H. Pettersson, and K. Martinsson. 1990. Comparison of plant estrogen levels in blood plasma from sheep and cattle after feeding on estrogenic silage. J. Agr. Food Chem. 38:1530-1534.

National Research Council. 1973. Toxicants occurring naturally in foods. Nat. Acad. Sci., Washington, D.C.

Oser, B.L. 1981. The rat as a model for human toxicological evaluation. J. Toxicol. Environ. Health 8:521-542.

Parke, D.V. (Ed.). 1975. Enzyme induction. Plenum Press, London.

Rankins, D.L., Jr., and G.S. Smith. 1991. Nutritional and toxicological evaluations of kochia hay (Kochia scoparia) fed to lambs. J. Anim. Sci 69:2925-2931.

Rankins, D.L., Jr., G.S. Smith, and D.M. Hallford. 1991a. Altered metabolic hormones, impaired nitrogen retention and hepatotoxicosis in lambs fed Kochia scoparia hay. J. Anim. Sci, 69:2932-2940.

Rankins, D.L., Jr., G.S. Smith, and D.M. Hallford. 1991b. Serum constituents and metabolic hormones in sheep and cattle fed Kochia scoparia hay. J. Anim. Sci. 69:2941-2946.

Rankins, D.L., Jr., G.S. Smith, and D.M. Hallford. 1991c. Effects of metoclopramide on steers fed Kochia scoparia hay. J. Anim. Sci. 69:3699-3705. 
Rozman, K., and O. Hanninen (Eds.). 1986. Gastrointestinal toxicology. Elsevier Science Publ., Amsterdam.

Ruofi, William. 1988. Enterohepatic circulation of estrogens in the domestic pig (Sus scrofa). Ph.D. Diss., Univ. Illinois, Urbana.

Seawright, A.A., M.P. Hegarty, L.F. James, and R.F. Keeler (Eds.). 1985. PIant toxicology. Animal Res. Inst., Yeerongpilly, Queensland 4105, Australia.

Smith, G.Stanley. 1986. Gastrointestinal toxifications and detoxifications in ruminants in relation to resource management. CH. 18 (p. 514-542). In: K. Rozman and O. Hanninen (Ed.), Gastrointestinal toxicology. Elsevier Science Publ., Amsterdam.

Smith, G.S., H.E. Kiesling, D.M. Hallford, D.L. Rankins, Jr., M.K. Erickson, R.E. Finkner, and C. French. 1989. Improving livestock tolerance of toxicants in kochia toward increased use as a water-efficient crop. Rep. 236, New Mexico Water Resources Res. Inst., New Mexico State Univ., Las Cruces.

Smith, G.S., J.B. Watkins, T.N. Thompson, K. Rozman, and C.D. Klassen. 1984. Oxidative and conjugative metabolism of xenobiotics by livers of cattle, sheep, swine and rats. J. Anim. Sci. 58:386-395.
Sprowls, R.W.1981. Problems observed in horses, cattle and sheep grazing kochia. Proc. 24th Annu. Meeting, Amer. Assoc. Vet. Lab. Diag., p. 397.

Thilstead, J., C. Hibbs, H. Kiesling, D. Hallford, R. Kirksey, A. Meininger, and J. Thompkins. 1989. Kochia (K. scoparia) toxicosis in cattle: results of four experimental grazing trials. Vet. Hum. Toxicol. 31:34-41.

Thompson, T.N., J.B. Watkins, Z. Gregus, and C.D. Klaassen. 1982. Effect of microsomal enzyme inducers on the soluble enzymes of phase II biotransformation. Toxicol. Appl. Pharmacol. 66:400-408.

USDA-ARS. 1990. Counteracting aflatoxin in livestock feed. Agr. Res. 38:18-19.

Van Soest, Peter J. 1982. Nutritional ecology of the ruminant. O \& B Books, Inc., Corvallis, Ore.

Watkins, J.B., III, and C.D. Klaassen. 1986. Xenobiotic biotransformation in livestock: comparison to other species commonly used in toxicity testing. J. Anim. Sci. 63:933-942.

Watkins, J.B., III, G.S. Smith, and D.M. Hallford. 1987. Characterization of xenobiotic transformations in hepatic, renal and gut tissues of cattle and sheep. J. Anim. Sci. 65:186-195. 